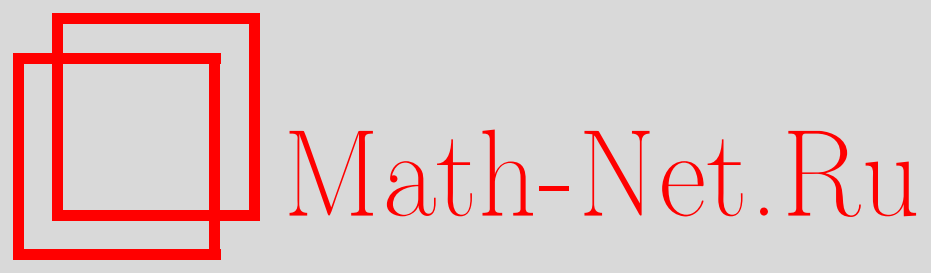

Информационное сообщение о симпозиуме CTCrypt'2020, Maтем. вопр. криптогр., 2021, том 12, выпуск 2, 5

DOI: https://doi.org/10.4213/mvk372

Использование Общероссийского математического портала Math-Net.Ru подразумевает, что вы прочитали и согласны с пользовательским соглашением http://www . mathnet.ru/rus/agreement

Параметры загрузки:

IP : 54.162 .85 .209

26 апреля 2023 г., 14:21:07

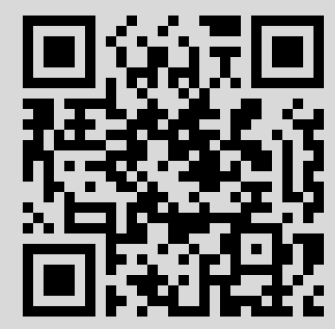




\section{Информационное сообщение о симпозиуме CTCrypt'2020}

С 15 по 17 сентября 2020 года в Подмосковье состоялся IX симпозиум «Современные тенденции в криптографии» (CTCrypt' 2020), в работе которого приняли участие порядка 100 делегатов, представляющих ведущие образовательные и научные учреждения, коммерческие организации и предприятия промышленности, деятельность которых тесно связана с исследованиями в области криптографии.

Тематика докладов, представленных на симпозиуме, была довольно обширна и включала не только вопросы синтеза и анализа классических симметричных и асимметричных схем, но и задачи широко обсуждаемых в последнее время квантовой и постквантовой криптографии.

Ввиду сложной эпидемиологической ситуации и закрытия государственных границ иностранные приглашенные докладчики приняли участие в работе симпозиума в дистанционном формате. Тиетсу Ивата (Япония) сообщил о результатах своих исследований, связанных с оценкой квантовой стойкости алгоритмов шифрования, построенных на основе сети Фейстеля. Мридул Нанди (Индия) рассказал об одной из наиболее насущных в настоящее время проблем, связанных с применением криптографии при реализации протоколов отслеживания контактов больных COVID-19. Доклад одного из выдающихся отечественных криптографов Игоря Арбекова был посвящен некоторым важным аспектам, связанным с применениями квантовой криптографии.

В рамках симпозиума был организован блок практической криптографии, где ведущие специалисты из различных организаций и ведомств поделились своим опытом решения различных актуальных задач.

Подача работ для участия в симпозиуме CTCrypt'2020 проходила в два этапа, что было обусловлено переносом сроков проведения симпозиума с уже привычного июня на сентябрь. В общей сложности для участия в симпозиуме было подано 36 работ, подготовленных коллективами из 9 стран. В процессе рецензирования были отобраны 23 работы. Часть работ публикуется в настоящем и последующих выпусках журнала. В соответствии с правилами симпозиума статьи публикуются на английском языке с аннотацией на русском языке.

Оргкомитет симпозиума 